\title{
STUDY ON THE PREVALENCE AND HEMATOLOGICAL ALTERATIONS IN TOXOPLASMA GONDII INFECTED CAPTIVE PHEASANT SPECIES OF BAHAWALPUR ZOO, PAKISTAN
}

\author{
M. H. Lashari' ${ }^{1}$, M. Bibi², U. Farooq3, F. Afzal ${ }^{1}$, A. Ali ${ }^{2}$, M. Safdar ${ }^{2}$ M. S. Akhtar ${ }^{4}$, A. A. Farooq ${ }^{4}$ S. Masood ${ }^{5}$ M. Ayaz \\ and M. I. Khan ${ }^{7}$ \\ ${ }^{1}$ Department of Zoology, The Islamia University of Bahawalpur, Pakistan \\ ${ }^{2}$ Virtual University of Pakistan; ${ }^{3}$ University College of Veterinary and Animal Sciences, The Islamia University of \\ Bahawalpur; ${ }^{4}$ Faculty of Veterinary Sciences, B.Z. University, Multan; ${ }^{5}$ Institute of Pure \& Applied Biology, B.Z. \\ University, Multan; ${ }^{6}$ Department of Parasitology, Cholistan University of Veterinary and Animal Sciences, Bahawalpur \\ ${ }^{7}$ School of Energy and Power Engineering, Xi'an Jiaotong University, 28 West Xianning Road, Xi'an 710049, Shaanxi, PR. China \\ Corresponding Author's email: mushtaqlashary@gmail.com
}

\begin{abstract}
The purpose of this study was to identify the seroprevalence of Toxoplasma gondii (T. gondii) and hematological alterations in captive pheasant species of Bahawalpur Zoo, Bahawalpur, Pakistan. The blood samples of 100 birds belonging to three different species viz. ring-necked pheasant (Phasianus colchicus) $(\mathrm{n}=46)$, green pheasant (Phasianus versicolor) $(\mathrm{n}=40)$, and silver pheasant (Lophura nycthemera) $(\mathrm{n}=14)$ were analyzed through Latex Agglutination Test (LAT) and Enzyme Linked Immunosorbent Assay (ELISA). Seroprevalance through LAT in ring-necked, silver and green pheasants was $10.86 \%, 7.14 \%$ and $7.5 \%$, and through ELISA was $32.60 \%, 22.5 \%$ and $14.28 \%$, respectively. Adults and males had higher prevalence as compared to their counterparts, though, statistically nn-significant $(\mathrm{P} \geq 0.05)$. In all the studied species, hematological results revealed that mean values of $\mathrm{Hb}$ and TEC were higher $(\mathrm{P} \leq 0.05)$ in noninfected birds as compared to infected ones. This is a preliminary study of a kind and needs further research with large number of sample and population across the country.
\end{abstract}

Keywords: Toxoplasma gondii, ELISA, LAT, Seroprevalance, Oocytes, Hematology parameters. https://doi.org/10.36899/JAPS.2021.2.0251

Published online October 03,2020

\section{INTRODUCTION}

Toxoplasma gondii (T. gondii) is an apicomplexan parasite which causes toxoplasmosis. $T$. gondii infection is more prevalent in birds and warmblooded animals including human (Dubey et al., 2010). Domestic cats and other felines (dog, lions, tiger etc.) are definitive hosts of $T$. gondii in which sexual phase of parasite occurs and asexual phase occurs in intermediate hosts such as birds and warm-blooded mammals (Dubey, 2010a). Definitive host of $T$. gondii plays a significant role in its transmission through resistant oocytes into the environment which may provide a chance for intermediate host to get infected. Definitive hosts become infected with this parasite by consuming infected tissues from intermediate host such as rodents or birds (Dubey, $2010 \mathrm{a}, \mathrm{b}$ ). There are various ways for the transmission of this parasite to its intermediate host. In humans, it is mostly transferred through consumption of raw/uncooked meat of infected livestock or birds (Dubey, 2010b). Birds become infected by taking oocysts from undercooked food, eating or drinking food and water contaminated with these oocysts. Birds are clinically resistant to $T$. gondii and are main source of infection in humans. (Dubey, 2010a).
Toxoplasmosis in birds and other animals (mammals including human) is often subclinical. In some cases, parasite causes symptoms in birds such as weight loss, lack of appetite, depression, diarrhea and decline in health. Seroprevalence of toxoplasmosis in wild and domestic birds such as pheasants, peafowls, partridges and owls has earlier been determined through enzymelinked immunosorbent assay (ELISA), Latex Agglutination Test (LAT), Modified Agglutination Test (MAT) and Indirect Hemaggultination Test (IHA). Birds feed directly from soil, when they feed from contaminated soil with $T$. gondii oocytes they get infection. So, the prevalence study of $T$. gondii in birds is also used as an indicator of soil contamination (Zhang et al., 2014). Studies on the prevalence of antibodies to $T$. gondii in animals can be useful tools in the determination of exposure within a population. There are a variety of serological methods to examine animal exposure to $T$. gondii. The MAT is often carried out as a test for the detection of infected birds as it shows high sensitivity and specificity, and it is can be used in multiple species (Dubey, 2010b; Jakubek et al., 2012).

The common pheasant (Phasianus colchicus) is a gallinaceous bird belonging to family Phasianidae and originates from central and eastern Asia. They have been 
introduced worldwide including New Zealand, Europe, Australia, North, and South America. Pheasants are considered as best source of meat in many parts of the world (dos Santos et al., 2007). There is scanty information regarding $T$. gondii seroprevalance in pheasants. In previous records, $2.4 \%$ prevalence of $T$. gondii in pheasants from Czech Republic has been reported by Literak et al. (1992). Pheasants feed consists of insects, grains and seeds. Different plumaged pheasants are present in Punjab and Sindh Province of Pakistan. A large population of pheasants is located in district Mansehra, Khyber Pakhtunkhwa. Pheasants are also being kept under captivity in Pakistan.

The main objective of this study was to assess seroprevalance of $T$. gondii in captive pheasants and alterations in hematological attributes of infected and non-infected pheasants.

\section{MATERIALS AND METHODS}

Blood samples from 100 pheasants including ring-necked $(n=46)$, green $(n=40)$ and silver $(n=14)$ pheasants from Bahawalpur zoo, Bahawalpur were collected from June 2018 to February 2019. Blood was drawn from vena ulnaris cutanea in disposable syringe, using safety clothes and gloves to avoid any contamination. Total $3 \mathrm{~mL}$ of blood was collected in vacutainers. About $1.5 \mathrm{~mL}$ of the blood was immediately transferred in aliquot coated with EDTA to prevent blood clotting for hematology analysis. Remaining blood was taken in aliquot without anticoagulant for serum analysis. Serum was harvested and stored for further analyses.

\section{Serological diagnosis}

Latex Agglutination Test: The commercial agglutination kit (TOXO-100T, Antec Diagnostic Products, UK, CAT 151009) was used to detect Toxoplasma-specific antibodies in serum of hosts. Samples and reagents were brought to room temperature. The assay was performed according to the instructions manual.
Enzyme Linked Immunosorbent Assay: The test procedure was carried out according to the method described by Lind et al., (1997) using CALBOTECH Toxoplasma IgG ELISA kit (Cenix Diagnostic GmbH, Germany, TOXOG 37305A) as per manufacturer's instructions.

Hematological analysis: For hematological analysis, Vitalab Flexor E Automatic Analyzer (Netherland) was used. The analyzer was meant for human blood samples and hence, was off-hand validated through blood samples of various birds. The values of different hematological attributes such as hemoglobin ( $\mathrm{Hb})$, Total Erythrocytic Count (TEC), Total Leukocytic Count (TLC), hematocrit (HCT), Mean Corpuscular Volume (MCV), Mean Corpuscular Hemoglobin (MCH), and Mean Corpuscular Hemoglobin Concentration (MCHC) were determined.

Statistical analysis: The data was arranged as per age (young and adult), gender (male and female), and species (ring-necked, green and silver pheasants). The prevalence was compared by implying Chi-square through Minitab Version 13 and the hematological attributes between infected and non-infected birds were compared by using independence t-test through SPSS (SPSS for Windows Version12, SPSS Inc., Chicago, IL, USA).

\section{RESULTS}

The overall prevalence found in present study was 9 and 26\% using LAT and ELISA, respectively (Table 1). Age-wise, higher prevalence was recorded in adult hosts as compared to young ones. Similarly, genderwise results revealed that higher prevalence was recorded in males as compared to females. Species-wise results showed slightly higher seroprevalence in ring-necked pheasants both through LAT and ELISA (Table 1). All these results were, though, statistically non-significant $(\mathrm{P} \geq 0.05)$.

In all the studied species, hematological results revealed that mean values of $\mathrm{Hb}$ and TEC were higher $(\mathrm{P} \leq 0.05)$ in non-infected birds as compared to infected ones (Table 2).

Table 1. The seroprevalence of Toxoplasma gondii on the basis of species, gender and age in captive pheasants by using LAT and ELISA.

\begin{tabular}{cccccccc}
\hline \multirow{2}{*}{ Parameters } & $\begin{array}{c}\text { No. of } \\
\text { hosts } \\
\text { observed }\end{array}$ & $\begin{array}{c}\text { Prevalence By Using } \\
\text { Latex Agglutination }\end{array}$ & $\begin{array}{c}\text { No. of Infected Host } \\
\text { Square }\end{array}$ & $\begin{array}{c}\text { P- } \\
\text { Value }\end{array}$ & $\begin{array}{c}\text { Prevalence By } \\
\text { using ELISA }\end{array}$ & $\begin{array}{c}\text { Chi- } \\
\text { Square }\end{array}$ & $\begin{array}{c}\text { P- } \\
\text { Value }\end{array}$ \\
\hline Overall Prevalence & 100 & \multicolumn{2}{c}{$\begin{array}{c}9(9 \%) \\
\text { Age }\end{array}$} & & & & $26(26 \%)$ \\
Young & 36 & $2(5.55 \%)$ & 0.815 & 0.36 & $7(19.44 \%)$ & \\
Adult & 64 & $\begin{array}{c}7(10.93 \%) \\
\text { Gender }\end{array}$ & & & $19(29.68 \%)$ & 0.815 & 0.36 \\
Male & 49 & $6(12.24 \%)$ & 1.23 & 0.26 & $13(26.53 \%)$ & 1.23 & 0.26 \\
\hline
\end{tabular}




\begin{tabular}{cccccccc}
\hline Female & 51 & $\begin{array}{l}3(5.88 \%) \\
\text { Species wise prevalence }\end{array}$ & & $13(25.49 \%)$ & & \\
Ring necked Pheasants & 46 & $5(10.86 \%)$ & & & & \\
Green necked Pheasants & 40 & $3(7.5 \%)$ & 2.27 & $0.36 \%)$ & $9(22.5 \%)$ & 0.36 & 0.833 \\
Silver Pheasants & 14 & $1(7.14 \%)$ & & & $2(14.28 \%)$ & & \\
\hline
\end{tabular}

Table 2. Mean \pm SEM values of hematology in infected and non-infected pheasants.

\begin{tabular}{|c|c|c|c|c|c|c|}
\hline \multirow{2}{*}{$\begin{array}{l}\text { Parameters' } \\
\text { Hematology }\end{array}$} & \multicolumn{3}{|c|}{$\begin{array}{l}\text { Infected hosts } \\
\text { Mean } \pm \text { S.EM }\end{array}$} & \multicolumn{3}{|c|}{$\begin{array}{l}\text { Non- infected Hosts } \\
\text { Mean } \pm \text { S.EM }\end{array}$} \\
\hline & $\begin{array}{c}\text { Ring necked } \\
\text { pheasants }\end{array}$ & $\begin{array}{c}\text { Green } \\
\text { pheasants }\end{array}$ & $\begin{array}{c}\text { Silver } \\
\text { Pheasants }\end{array}$ & $\begin{array}{l}\text { Ring necked } \\
\text { pheasants }\end{array}$ & $\begin{array}{c}\text { Green } \\
\text { pheasants }\end{array}$ & $\begin{array}{c}\text { Silver } \\
\text { pheasants }\end{array}$ \\
\hline $\begin{array}{l}\text { Hemoglobin } \\
\text { g/dl }\end{array}$ & $17.7 \pm 0.8^{\mathrm{a}}$ & $17.4 \pm 0.5^{\mathrm{a}}$ & $17.4 \pm 1.8^{\mathrm{a}}$ & $18.4 \pm 0.2^{\mathrm{b}}$ & $18.8 \pm 0.4^{b}$ & $18.1 \pm 0.8^{b}$ \\
\hline $\begin{array}{l}\text { Total } \\
\text { RBC } / \mathbf{m m}^{3}\end{array}$ & $2.5 \pm 0.08^{\mathrm{a}}$ & $2.5 \pm 0.1^{\mathrm{a}}$ & $2.7 \pm 0.1^{\mathrm{a}}$ & $2.6 \pm 0.05^{\mathrm{b}}$ & $2.6 \pm 0.09^{b}$ & $3.0 \pm 0.06^{\mathrm{b}}$ \\
\hline НСТ \% & $39.2 \pm 1.7^{\mathrm{a}}$ & $42.4 \pm 1.7^{\mathrm{a}}$ & $40.0 \pm 5.8^{\mathrm{a}}$ & $40.7 \pm 0.91^{\mathrm{a}}$ & $39.5 \pm 1.1^{\mathrm{a}}$ & $40.5 \pm 2.3^{\mathrm{a}}$ \\
\hline MCV f/l & $144.7 \pm 2.8^{\mathrm{a}}$ & $144.3 \pm 3.6^{\mathrm{a}}$ & $146.8 \pm 12.7^{\mathrm{a}}$ & $145.8 \pm 1.0^{\mathrm{a}}$ & $147.2 \pm 1.2^{\mathrm{a}}$ & $144.5 \pm 7.2^{\mathrm{a}}$ \\
\hline МCH pg & $57.7 \pm 2.2^{\mathrm{a}}$ & $52.3 \pm 2.0^{\mathrm{a}}$ & $60.7 \pm 8.8^{\mathrm{a}}$ & $59.0 \pm 1.3^{\mathrm{a}}$ & $56.4 \pm 1.4^{\mathrm{a}}$ & $60.9 \pm 3.0^{\mathrm{a}}$ \\
\hline МCHC G/dl & $42.2 \pm 0.3^{\mathrm{a}}$ & $42.2 \pm 0.3^{\mathrm{a}}$ & $42.6 \pm 0.4^{\mathrm{a}}$ & $41.9 \pm 0.2^{\mathrm{a}}$ & $42.6 \pm 0.2^{\mathrm{a}}$ & $41.8 \pm 0.5^{\mathrm{b}}$ \\
\hline Platelets/mm^3 & $2143 \pm 340^{\mathrm{a}}$ & $2533 \pm 322^{\mathrm{a}}$ & $3333 \pm 667^{\mathrm{a}}$ & $2563 \pm 195^{\mathrm{a}}$ & $1968 \pm 176^{\mathrm{a}}$ & $2245 \pm 493^{\mathrm{a}}$ \\
\hline $\mathbf{T L C} / \mathbf{m m}^{\wedge} 3$ & $148357 \pm 650^{\mathrm{a}}$ & $101067 \pm 32479^{\mathrm{a}}$ & $40700 \pm 3816^{\mathrm{a}}$ & $137017 \pm 30549^{\mathrm{a}}$ & $146238 \pm 29364^{\mathrm{a}}$ & $51036 \pm 7783^{\mathrm{a}}$ \\
\hline Neutrophils & $4.4 \pm 0.9^{\mathrm{a}}$ & $5.4 \pm 0.6^{\mathrm{a}}$ & $2.0 \pm 0.01^{\mathrm{a}}$ & $5.0 \pm 0.3^{\mathrm{a}}$ & $5.1 \pm 0.3^{\mathrm{a}}$ & $4.2 \pm 0.7^{\mathrm{a}}$ \\
\hline $\begin{array}{l}\text { Lymphocytes } \\
\%\end{array}$ & $87.2 \pm 3.2^{\mathrm{a}}$ & $88.5 \pm 1.5^{\mathrm{a}}$ & $88.3 \pm 4.6^{\mathrm{a}}$ & $87.1 \pm 1.1^{\mathrm{a}}$ & $87.1 \pm 1.2^{\mathrm{a}}$ & $86.3 \pm 2.0^{\mathrm{a}}$ \\
\hline Monocytes \% & $2.8 \pm 0.9^{\mathrm{a}}$ & $3.8 \pm 0.6^{\mathrm{a}}$ & $1.6 \pm 0.3^{\mathrm{a}}$ & $4.3 \pm 0.5^{\mathrm{a}}$ & $4.8 \pm 0.5^{\mathrm{a}}$ & $4.6 \pm 0.9^{\mathrm{a}}$ \\
\hline Eosinophils \% & $3.1 \pm 0.8^{\mathrm{a}}$ & $3.0 \pm 0.5^{\mathrm{a}}$ & $2.0 \pm 0.5^{\mathrm{a}}$ & $2.9 \pm 0.3^{\mathrm{a}}$ & $2.2 \pm 0.2^{\mathrm{a}}$ & $2.7 \pm 0.6^{\mathrm{a}}$ \\
\hline
\end{tabular}

The different superscripts showed significantly difference between infected and non-infected hosts within columns

\section{DISCUSSION}

The present study is the first of its kind being reported with an aim of presenting seropravelence of Toxoplasma gondii in various species of pheasants kept under captivity in Bahawalpur zoo, Bahawalpur. It also caters the objective of analyzing hematological attributes in Toxoplasma infected and non-infected pheasants.

According to this study, the overall seroprevalance through LAT was $9 \%$ and through ELISA was $26 \%$. A lower prevalence in pheasants has been reported by Literak et al., (1992) from Czech Republic being $2.4 \%$. Various studies have reported different prevalence rates worldwide in various birds such as in wild birds (89.6\%), chukars (67\%), rufous bellied thrush $(63.1 \%)$, partridges $(55 \%)$ turkeys $(40 \%)$, guinea fowls (22\%), and pheasants (0\%) (Karakavuk et al., 2018), Sedlák et al., 2000, Gennari et al., 2014, Zhang et al., 2000). In Iran, a survey conducted by Amouei et al., (2018) in migrating and domestic birds determined a seroprevalance of $52 \%$ and $51.3 \%$, respectively. Similarly, a study performed by Uterák et al., (1992) in wild birds of Czech Republic found that the occurrence of $T$. gondii was $0.5 \%$ in house sparrows, $2 \%$ in pheasants, $8 \%$ in common buzzards, $12 \%$ in mallards, and $18 \%$ in rooks. In Turkey, $0.95 \%$ and $0.90 \%$ seroprevalance has been reported in domestic and wild pigeons, respectively by Karatepe et al., (2011). Most of the birds including pheasants are ground feeders, if soil is contaminated with parasite they have greater chance to get infected (Dubey et al., 2010). Seroprevalence of $T$. gondii in zoo-captive birds may be due to various management issues including mechanical transportation of oocytes shed by feral cats passing through zoo keeper dress, shoes or other cleaning tools.

In the present study, higher prevalence was observed in males than in females (Table 1). Similar results have been reported by Nath et al., (2014), Zhang et al., (2014), and Lashari et al., 2018 while contrasting results have been reported by Gicik and Arslan (2001) and Naqvi et al., (2017). Males are much less vulnerable than females to protozoan parasites. There may be different factors such as hormones related to gender, age, environmental factors and nutrition (Roberts et al., 2001) for these variations.

Age-wise higher prevalence was observed in adults as compare to young ones in our study (Table 1). The reasoning behind this may be that there would be more chances for adult animals to get infected than younger ones as suggested previously (Zhao et al., 2012). It has been noted in previous research that cats play a significant role in disease transmission to certain livestock, including birds (Yan et al., 2009; Zhao et al., 
2012). Adults have wide range of feeding than young ones so, they might be having more chance to get infected.

In all the studied species, hematological results revealed that mean values of $\mathrm{Hb}$ and TEC were higher $(\mathrm{P} \leq 0.05)$ in non-infected birds as compared to infected ones (Table 2). Low level of RBCs and HCT may indicate the loss of blood in gastrointestinal tract due to infection similar results are reported by Irizaary- Rovira (2004) and Wakenell (2010). Level of neutrophils increase in infection but its level is decreased in current study which is in contrast to previous results. Neutrophils have granules (lysosomal bodies) which help these cells to fight against various infections causing agents (Wakenell, 2010).

Basophils cell play significant role in birds in response to any infection or inflammation (Koutsos et al., 2007). High level of lymphocytes is reported in current study which play significant role to maintain immunity. The TLC helps to indicate the level of infection in birds and in other animals. Tonin et al., (2013) reported that higher percentage of lymphocytes was present in infected rats. TLC count indicates the state of immunity, high values may indicate infection, whereas low values indicate immunosuppression (Campbell, 1995).

Conclusion: On the basis of present study, it is concluded that overall prevalence of $T$ gondii in pheasants kept captive at Bahawalpur zoo, Bahawalpur is $9 \%$ by LAT and $26 \%$ by ELISA. The prevalence was higher in males and adult pheasants. Moreover, some of the hematological parameters were altered by $T$. gondii but not all, which helps us to assess the level of infection in hosts due to this parasite. In literature, scanty information is present regarding the prevalence and hematological alterations due to $T$. gondii in captive pheasants across the world. This is a preliminary research one of a kind that needs for further studies with larger populations across the world.

\section{REFERENCES}

Amouei, A., M. Sharif, S. A. Hosseini, S. Sarvi, A. Mizani, S. Salehi, and A. Daryani (2018). Prevalence of Toxoplasma gondii infection in domestic and migrating birds from Mazandaran province, Northern Iran. Avian Biol. Res., 11(1), 12-15.

Campbell, T.W. (1995). Avian hematology and cytology: $2^{\text {nd }} E d$. Iowa State Univ. Press

dos Santos Schmidt, E. M., A. C. Paulillo, R. L. Dittrich, E. Santin, P. C. L. da Silva, O. Beltrame and E. G. de Oliveira (2007). The effect of age on hematological and serum biochemical values on juvenile ring-necked pheasants (Phasianus colchicus). Int. J. Poult Sci., 6(6), 459-461.
Dubey J.P. (2010a) Toxoplasmosis of animals and humans. CRC Press, Taylor \& Francis Group. Boca Raton, FL.

Dubey, J.P. (2010b) Toxoplasma gondii infections in Chickens (Gallus domesticus): prevalence, clinical disease, diagnosis and public health significance. Zoonoses Public Hlth., 57, 60-73.

Dubey, J., T. Felix and C. Kwok (2010). Serological and parasitological prevalence of Toxoplasma gondii in wild birds from Colorado. J. Parasitol., 5 (96), 937-939.

Gennari, S. M., M. Ogrzewalska, H. S. Soares, D. G. Saraiva, A. Pinter, M. B. Labruna, and J. P. Dubey (2014). Occurrence of Toxoplasma gondii antibodies in birds from the Atlantic forest, state of São Paulo, Brazil. Vet. Parasitol. 200(1-2), 193-197.

Gicik, Y. and M.Ö. Arslan. 2001. Blood parasites of wild pigeons in Ankara District. Turk. J. Anim. Sci. 25(2): 169-172.

Irizaary-Rovira, A.R. (2004). Avian and reptilian clinical pathology (Avian hematology and biochemical analysis). Section XI. Vet. Clin. Pathol. Secrets. Elsevier, St. Louis. 282-313.

Jakubek, E.B., R. Mattsson, T. Morner, J.G. Mattsson and D. Gavier- Widen (2012). Potential application of serological tests on fluids from carcasses: detection of antibodies against Toxoplasma gondii and Sarcoptes scabiei in Red Foxes (Vulpes vulpes). Acta Vet. Scand. 54, 1317.

Karakavuk, M., D. Aldemir, A. Mercier, E. A. Şahar, H. Can, J. B. Murat and B. Pektaş (2018). Prevalence of toxoplasmosis and genetic characterization of Toxoplasma gondii strains isolated in wild birds of prey and their relation with previously isolated strains from Turkey. PloS One. 13(4): e0196159.

Karatepe1, M., S. Kılıç, B. Karatepe and C. Babür. 2011. Prevalence of Toxoplasma gondii antibodies in domestic (Columba livia domestica) and wild (Columba livia livia) pigeons in Nigde region, Turkey. Turk. Parazitol. Derg. 35: 23-26.

Koutsos, E.A., J.C.G. Lopez and K.C. Klasing. (2007). Maternal and dietary arotenoids interactively affect cutaneous basophil responses in growing chickens (Gallus gallus domesticus). Comp Biochem Physiol B Biochem Mol Biol. 147(1): 87-92.

Lashari, M.H., F. Afzal and U. Farooq. (2018). Hematological changes in free-range chicken (Gallus domesticus) naturally infected with Toxoplasma gondii. Sarhad J. Agric. 34(4): 973978. 
Lind, P., J. Haugegaard, A. Wingstrand and S.A. Henrisken (1997). The time course of the specific antibody response by various ELISAs in pigs experimentally infected with Toxoplasma gondii. Vet. Parasitol., 71: 1-15.

Literak, I., K. Hejkek, J. Nezval and Folk (1992). Incidence of Toxoplasma gondii in pop- ulations of wild birds in Czech Republic. Avian Pathol. $21,659-665$.

Naqvi, M.A.U.H., M.K. Khan, Z. Iqbal, H.M. Rizwan, M.N. Khan, S.Z. Naqvi, A. Zafar, R.Z. Abbas and A. Abbas. 2017. Prevalence and associated risk factors of haemoparasites, and their effects on hematological profile in domesticated chickens in District Layyah, Punjab, Pakistan. Prev. Vet. Med. 143: 49-53.

Nath, T.C., M.J.U. Bhuiyan and M.S. Alam (2014). A study on the presence of leucocytozoonosis in pigeon and chicken of hilly districts of Bangladesh. IBSPR. 2 (2): 013-018.

Roberts, C.W., W. Walker and J. Alexander (2001). Sexassociated hormones and immunity to protozoan parasites. Clin. Microbiol. Rev. 14(3): 476-488.

Sedlák, K., I. Literák, F. Vitula and J. Benak (2000). High susceptibility of partridges (Perdix perdix) to toxoplasmosis compared with other gallinaceous birds. Avian Pathol. 29(6): 563569.

Tonin, A.A., A.S. da Silva, M.L. Thorstenberg, L.G. Castilhos, R.T. Franca, D.B.R. Leal, M.M.M.F. Duarte, F.S.F. Vogel, M.L. de La Rue and S.T. dos Anjos Lopes. (2013). Influence of
Toxoplasma gondii acute infection on cholinesterase activities of Wistar rats. Korean J. Parasitol. 51(4): 421-425.

Uterák, I., Hejlícek, K., Nezval, J., and C. Folk (1992). Incidence of Toxoplasma gondii in populations of wild birds in the Czech Republic. Avian Pathol. 21(4), 659-665.

Wakenell, P.S. (2010). Hematology of chickens and turkeys. Schalm's Veterinary Hematology.p.958-967: 6th Ed. WileyBlackwell, USA.

Yan, C., C.L. Yue, Z.G. Yuan, Y. He, C.C. Yin, R.Q. Lin, J.P. Dubey and X.Q. Zhu (2009). Toxoplasma gondii infection in domestic ducks, free-range and caged chickens in southern China. Vet. Parasitol. 165(3): 337-340.

Zhang, S. Y., M. X. Wei, , Z. Y. Zhou, J. Y. Yu and X. Q. Shi (2000). Prevalence of antibodies to Toxoplasma gondii in the sera of rare wildlife in the Shanghai Zoological Garden, People's Republic of China. Parasitol. Int. 49(2); 171174.

Zhang, X. X., N. Z. Zhang, W. P. Tian, D. H. Zhou, Y. T. $\mathrm{Xu}$, and X. Q. Zhu (2014). First report of Toxoplasma gondii seroprevalence in pet parrots in China. Vector Borne Zoonotic Dis. 14(6): 394-398.

Zhao, G., B. Shen, Q. Xie, L.X. Xu, R.F. Yan, X.K. Song, I.A. Hassan and X.R. Li. (2012). Detection of Toxoplasma gondii in free-range chickens in China based on circulating antigens and antibodies. Vet. Parasitol. 185(2): 72-77. 